\title{
Predictable Impact of Current Economic Recession on the Spread and Severity of Diseases in African Countries: Focus on Nigeria
}

\section{Bamgboye M Afolabi}

Health, Environment and Development Foundation, 18 Ogunfunmi Street, off Akobi Crescent, Surulere, Lagos, Nigeria

Corresponding author: Bamgboye M Afolabi, Health, Environment and Development Foundation, Nigeria, Tel: +234 (0) 8058658029 ; Email: bmafolabi@gmail.com

Received date: February 06, 2016; Accepted date: April 17, 2016; Published date: April 21, 2016

Citation: Afolabi BM. Predictable Impact of Current Economic Recession on the Spread and Severity of Diseases in African Countries: Focus on Nigeria. J Prev Inf Cntrl. 2017, 3:1

Copyright: (c) 2017 Afolabi BM. This is an open-access article distributed under the terms of the Creative Commons Attribution License, which permits unrestricted use, distribution, and reproduction in any medium, provided the original author and source are credited.

\section{Abstract}

This paper hypothesizes the health effect of current economic recession in sub-Saharan African countries, especially Nigeria, and how this is projected to impact especially the child health. Malnutrition is expected to be the bed-rock of other diseases, though this may not be a new phenomenon but one that has not been adequately addressed. Most $(71 \%)$ children in sub-Saharan Africa suffer from child-poverty, and may be stunted, wasted and malnourished. Over-riding disease that may super-impose on malnutrition are bacterial diseases such as pneumonia, cholera, typhoid and Cancrum oris (NOMA), viral diseases such as measles, hepatitis, resurgence of polio, helminthic diseases such as Necator americanus and parasitic diseases such as malaria. The severity of these diseases is consequent upon two major factors which are out-of-pocket expenditure and caliber of health system in the nation. The main task is for the African Union and sub-Saharan governments at all levels to institute Child Health Insurance, Child Support Grant, Women Health Insurance and Women Support Grant for the protection and support of every African child and woman. The African Union should also constitute a special task force on overall health of African children and women.

Keywords: Economic crisis; Malnutrition; Disease spread and severity; Sub-Saharan Africa; Child health insurance; Child support grant; African union

\section{Introduction}

In recent years, many African countries have gone through some measures of economic meltdown, increase in population which outstrips economic growth, or both economic recession and population increase, lasting as short as one or two years while most linger on almost indefinitely.

In addition, natural disasters such as flood, inclement weather, desertification, ocean surge and drought have wreaked havoc in many African countries, wiping away communities. Man-made disasters such as internecine war, territorial invasion, insurgency and religious conflicts have also decimated human lives or caused massive displacement of people from their homelands. In 2014, the Ebola epidemic struck, with its epicenter in Guinea and quickly spreading through neighboring Liberia and Sierra Leone to reach as far as Mali, Senegal and Nigeria. Added to this is sharp increase in the price of fuel. These have put heavy burden on government expenditures.

The most famous economic crisis of the 20th Century occurred in United States of America and lasted for 10 years (1929-1939) during which both cardiovascular and tuberculosis mortality peaked in 1926, 1928 and mortality due to flu/ pneumonia was evident in the late 1920s [1]. During the American depression, approximately $20 \%$ of children suffered hunger and lack of proper clothing and in some areas, especially in the coal-mining regions; the prevalence of childhood malnutrition was as high as $90 \%$ [2]. There has also been economic depression in other parts of the world such as the Latin America that reported a high prevalence of stunting during the crisis. The short-term financial crisis that occurred in Peru between 1989-1990 and in Mexico in 1999 witnessed sharp rises in infant and under-five mortalities in those countries $[3,4]$.

In the past two decades, Egypt's population growth rate of 2.4\% per year makes it among the highest in the world [5] which triggers a concern for the public because of the severe economic crisis facing the country [6]. Economic depression or economic recession ultimately translates to the situation where, without war, and natural disasters, human life is threatened, characterized by high rate of unemployment, reduced money in circulation, and inflation. Economic depression or recession impacts almost all facets of life-agriculture, education, trade, family bond, travels, leisure, housing and health.

Previous economic crises, whether moderate or severe, had almost always resulted in a rise in infant mortality due to children dying of malnutrition and child labor. As Harper et al. noticed, during economic crisis, parents would be unable to support households or ensure greater child protection and wellbeing of their families [7].

The French Revolution (1789-1799) could be traced to feudal oppression and fiscal mismanagement among other things [8]. 
Recently, economic crises hit many South Asian countries in 2007 and, as Cader and Perera observed, "The effects are still being felt, especially in poorer developing nations where the number of infant deaths is still quite high, nutrition of children and women continues to be problematic and maternal health and pre-/post-natal care remains poor" [9]. It is common knowledge that, during recession, cost of living rises and children, the most affected at-risk group, are challenged with life-threatening malnutrition, which is already prevalent in Africa (Figure 1) and other diseases.

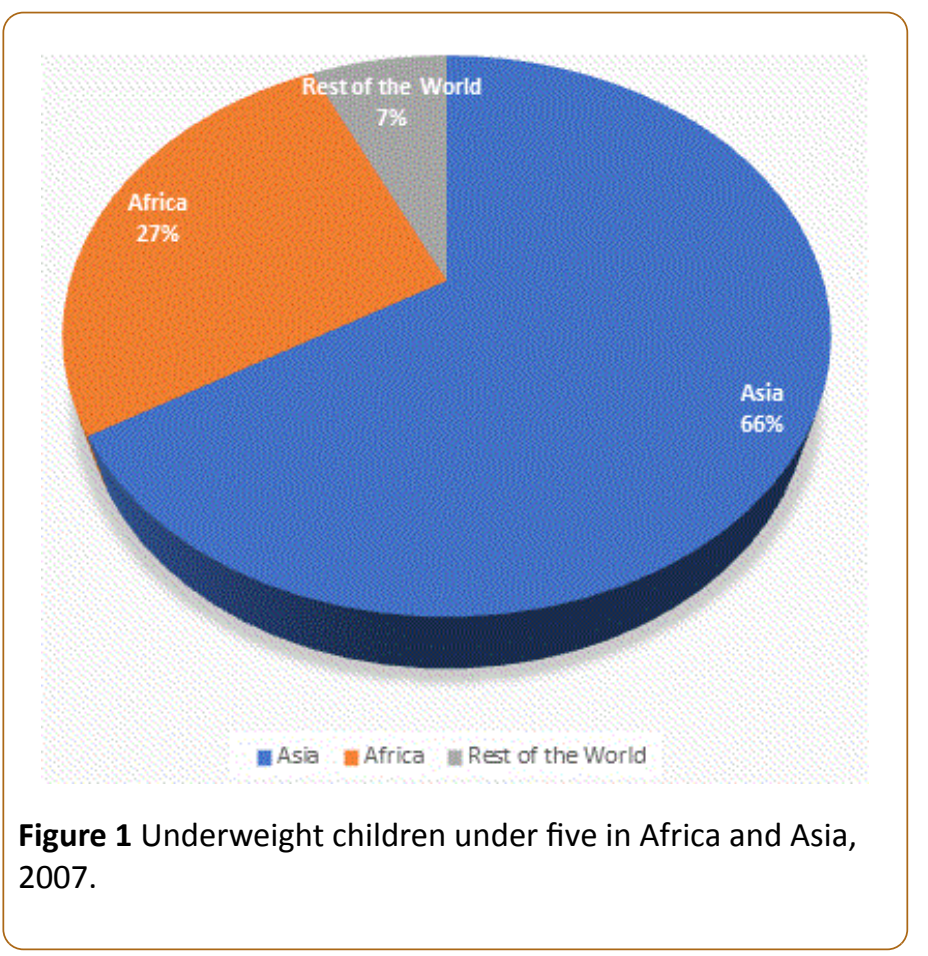

The volatility of existing global economy is causing ripples of uncertainty and risk in all areas of life in Africa, especially in the health sector. Economic recession is not new to Africa where many countries such as Ghana, Ethiopia, Zimbabwe and South Africa, just to mention a few, have faced serious consequences of the crisis. However, almost all data on economic crisis present a retrospective view of the impact of economic downturn on health of general or specific populace long after the situation had abated. Data on predictable and prospective health impact is hard to come by. The essence of a predictive study is to alert authorities of the impending impact of fiscal disaster on the health of people, though a prospective and cross-sectional study would be even better and more authoritative. The objective of this paper, therefore, is to investigate the current economic recession in Nigeria and document its predictable impact of the spread and severity of diseases, especially among children.

\section{Statement of the problem}

The general outlook is that Africa struggled to demonstrate developments and advances in its health indicators towards achieving its Millennium Development Goal (MDG) targets (http://www.unmillenniumproject.org/goals/gti.htm). Not much progress was recorded in this regard before the expiration of the term of the MDG. The current global economic downturn coincides with the time when Africa's health financing started indicating enhancement through high economic growth averaging $5 \%$ per year in the past decade. However, the health sectors in a clear majority of sub-Saharan Africa are currently deeply dependent on external funding as well as out-of-pocket (OOP) expenditure by households.

Nigeria, with a population of approximately 180 million people, has an economy that is mainly dependent on crude oil, without much diversification. The drastic fall in global crude oil price has seriously weakened the economy leading to high cost of living, high rate of unemployment and shift towards living below poverty line for many people who were hitherto either on the borderline or slightly above the borderline of poverty line. Middle-income earners have been dragged down to live around poverty line and, as yet, there may be some insignificant effects on high income earners. Still majority of the people have become poorer as ability to afford health care from out-ofpocket expenses has dwindled significantly. Cost of food, housing and medications have sky-rocketed and many people find it difficult to eat nourishing food causing food-borne, and water-borne diseases such as cholera and typhoid. Electricity supply, which was not regular before, is now currently scarcely available. In-door heat drives people to open their windows at night to cooling air and to mosquito bites. Many people are flocking to religious houses to pray that the situation will abate through divine intervention - a favorable situation for the spread of diseases such as tuberculosis. Consideration of hygiene in food preparation and hand washing may be absent and children may likely develop diarrhea. Pregnant women with their fetuses and adults are not exempted from the impact of economic crisis as far as their health is concerned. A report reads:

"Global economic slowdown massive job cuts, rising unemployment, falling family incomes, rising inflation (consumer price index) are indicators of recession in Nigeria not to mention the ripple effects on Nigerians" [10]. As succinctly put by a tabloid newspaper: "Nigeria is in a recession, economy going from bad to worse. Prices of commodities have double purchasing power has diminished. All these come at a cost: a rise in mental health disorders" [11]. But the cost is more than mental health disorders, it involves the totality of the health of individuals, especially that of children. Thus, the focus of the review was on disease prevalence, spread and severity during economic crisis of various durations and in different countries.

\section{Hypothesis}

The hypothesis driving this study is that childhood diseases, including vaccine preventable illnesses, are more likely to be rampant during the current economic recession than when there was no economic recession in Nigeria. Also resource to ameliorate these childhood diseases will be scarce, leading to elevated morbidity and mortality.

\section{Materials and Method}

PubMed, Medline, "Cochrane Library and EmBase data-bases" were searched for relevant information on the topic from 1929 to 2016, not limited to any particular country. Medical Subject Headings, subheadings and key words searched included, but 
were not limited to "economic crisis," "economic depression," "economic recession," "economic recession and child health," "economic depression and child health," "economic crisis and maternal health," economic crisis and national health," "economic crisis and health of Africans," "economic downturn," "economic crisis in Africa," "economic recession in Nigeria," "Nigerian economic crisis and health," "Impact of economic crisis on children," "impact of economic crisis on women and children," "Global economic recession and Health Indicators," "Infant and Child morbidity and mortality during economic crisis," "Disease transmission during economic crisis," "Disease severity during economic crisis" and "Impact of economic crisis on pregnant women." Search engines were also used to source for documentations and historical facts on the Great Depression of 1929-1932 in United States of America and the French Revolution of 1789-1799. Valuable insights on impact of Global Economic crisis on Health in Africa were gained from a survey of country Missions of the United States Agency for international Development (USAID). Finally, open discussions were help with other colleagues in the medical and pharmacological field, with a consultant microbiologist and a social scientist. Some of the responses were "economic recession"[MeSH Terms] OR ("economic"[All Fields] AND "recession"[All Fields]) OR "economic recession"[All Fields]) AND ("disease"[MeSH Terms] OR "disease"[All Fields] OR "diseases"[All Fields]) AND ("africa"[MeSH Terms] OR "africa"[All Fields]).

\section{Annotations and Discussion}

\section{Expected impact on children}

Currently, there is no accurate data on how many Nigerian children are unable to meet the basic needs such as food, healthcare services, education and shelter [12]. Child poverty, in its most basic definition can be said to relate to the inability of the child to meet some, if not all, of these basic needs. It is estimated that, even before the current economic crisis in the country, at least 10 million Nigerian children were deprived of a minimum of 2 of these needs, especially when the internally displaced persons (IDPs) are taken into consideration. About 10-20 million children are predicted to be challenged with the risk of various forms of diseases and sickness occasioned by poor or complete lack of sanitation. Anecdotal reports and observations have shown that, already, people are devising ways and means to cut corners and escape the economic crunch.

Be that as it may, certain diseases are expected to emerge during the economic crunch which predictable diseases are discussed below:

\section{Gastroenteritis-cholera and typhoid}

As economic recession progresses, little regard will be paid to hygienic preparation of food, utensil- and dish-washing, as well as hand washing because funds to purchase soap and detergents are unavailable. Yes, it is alarming, but before the recession and even now, people buy water (Figures 2 and 3) mainly from unhygienic sources, in unhygienic containers. This is expected to exacerbate the spread of water-borne diseases further.

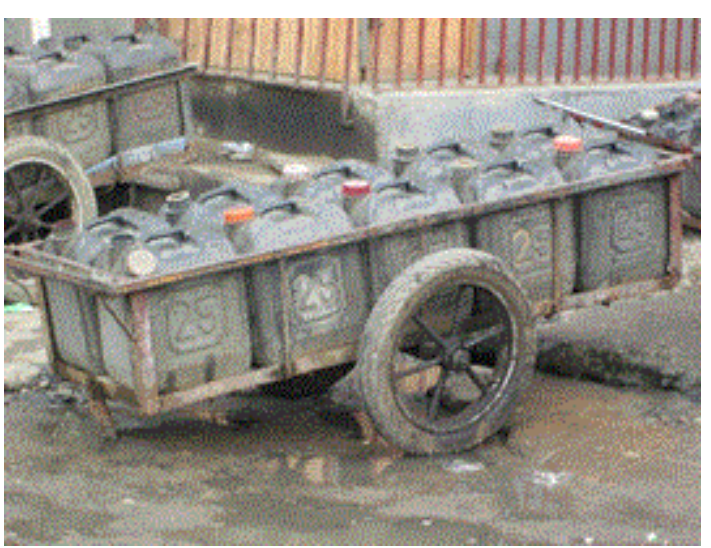

Figure 2 Unhygienic source of water in a Nigerian city.

Those who patronize local restaurants should be ready to contend with the spread of diseases such as cholera (Vibrio cholera) and typhoid (Salmonella typhii/paratyphii) because of the same unhygienic preparation of food and declined attention to personal health. This is a good avenue for a possible increase in cases of gastroenteritis and helminthiasis.

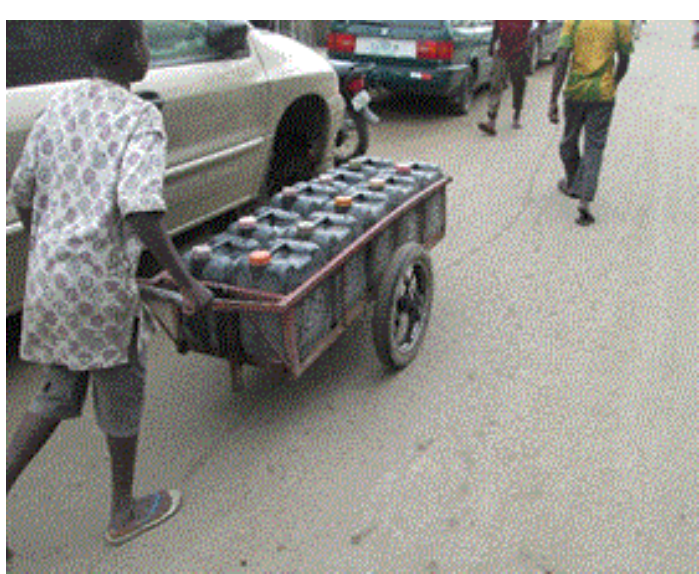

Figure 3 Young boy selling water instead of being in school.

\section{Avitaminosis and lack of essential minerals}

The costs of vegetables and fruits have risen by between 200-300\% and children's food will be devoid of vitamin A which, if prolonged, may lead to Vitamin A deficiency and night blindness. Parents may not be able to afford citrus fruits that supply Vitamin $C$ to the body, predisposing children to scurvy. Although the cost of cassava has also risen, it may still be affordable and this may be the staple food. The problem however, is that cassava is a starchy food which contains some concentration of Potassium thiocyanate that has been linked to Tropical Ataxia Neuropathy [13] and thiamine deficiency characterized by sensory polyneuropathy, sensory ataxia, bilateral optic atrophy and bilateral sensorineural deafness [14]. Food rich in protein is almost completely out of the equation as meat, chicken and fish area almost beyond the reach of the poor people. Absence of these commodities in the daily diet of the child means that infants and children below the age of 5 years 
especially, will be deprived of vital amino acids and essential elements such as zinc, magnesium, calcium. These deficiencies may affect their adult psychosocial life.

\section{Leptospirosis}

Waste and sewage disposal are expected to be affected by the economic recession as household and industrial wastes would likely litter many homes and streets, attracting rodents, vermin and other dangerous insects and pests. Rodents such as rats (Ratus ratus) are expected to invade human habitation and may probably cause leptospirosis through their urine on food stuff, cans and other household utensils. In addition, the expected increase in the population of house-flies (Musca domestica) due to piled-up garbage and refuse and to lack of sewage disposal is expected to predispose to diarrhea diseases in children.

\section{Mosquito-borne diseases-malaria, zika (and microcephaly)}

The last nationwide distribution of Long-Lasting Insecticidal Nets (LLINs) was about 4 years ago, and is now expected to be torn or expired. There may be no replacement of these nets in at least the next 2-3 years such that children and pregnant women would now be more exposed to mosquito bites. A recent report indicated that mosquito-borne Zika may be transmitted to some African countries, Nigeria included [15]. Exposure of pregnant women to mosquito bites may indicate that Zika virus may be introduced through this means to Nigeria with an expected rise in the prevalence and incidence of microcephaly (Refer to Table and graphs).

\section{Bacterial diseases-Septicemia, pneumonia, tuberculosis,} tetanus and cancrum oris (NOMA)

\section{Pneumonia, septicemia and cerebrospinal meningitis}

Between 2000 and 2003, pneumonia was responsible for the death of an estimated $20 \%$ of under- 5 years old children in Nigeria and by 2007 , the under-5 mortality rate was $197 / 1000$, a figure far exceeding the 70/1000 Millennium Development Goals target to be achieved by 2015 [16]. In a prospective cohort study in Ilorin, North-central Nigeria, the rate of acute respiratory infections (ARI) was 3 episodes/child/year with pneumonia being responsible for 13 episodes/child/year [16]. Earlier studies in Nigeria showed that Streptococcus pneumoniae accounted for 50-55\%, of community acquired cased in Northern and Eastern Nigeria respectively $[17,18]$ and more recent study indicates that it is responsible for $60 \%$ of community-acquired cases in Northern Nigeria city of Kano [19]. A recent study has shown that the pneumococci account for $46.4 \%$ of CAP, meningitis and bacteremia in the city of Kano in Northern Nigeria [20]. Lung aspirate studies in Nigeria identified a significant fraction of acute pneumonia cases to be due to Mycobacterium tuberculosis, which is notoriously difficult to identify in children [21].

Children may develop pneumonia when the immune system is lowered by other co-infections such as malaria and measles or influenza viremia. Children from poor families sleep either on cloth spread on bare floor or on mat. Pneumonia may be mild or severe and severe pneumonia may cause severe anaemia. Septicemia, a common complication of pneumonia occurs when the causative organism of pneumonia (Mycobacterium pneumoniae) spreads from the lungs into the blood stream. The outcomes of this spread include secondary metastatic infection of the meninges (meningitis), endocarditis and pleural effusion. The write-up hypothesizes a rise in the proportion of children with pneumonia in the next 3-4 years, if the economic recession continues.

Already, about 324 people, mostly children aged 5-14, across several states in the country have died of Cerebrospinal meningitis (CSM) since December 2016 with over 2,500 infected people in 16 of 36 states across Africa's most populous nation of about 180 million people. Efforts to curb the meningitis $C$ outbreak are hampered by a worldwide shortage of vaccine which may be directly related to the current global economic depression. Of the three million doses of CSM vaccine needed in the worst-hit state in the north of Nigeria, the World Health Organization has delivered only 500,000 [22].

\section{Tuberculosis}

Nigeria is currently ranked third among the 22 high TB burden countries responsible for about $80 \%$ of the global TB burden [23]. A study in Lagos found that childhood TB constitutes about $6.8 \%(5.9-7.6 \%)$ of the total TB cases notified between 2011-2014, though authors claimed that this could be an underestimation and that there was an increase in the case notification rate of TB among children between 2011 and 2014 [24]. They also suggested that a high level of TB transmission in the country

The spread and severity of tuberculosis would take a different pathway. During economic crisis, people, especially the poor, become more spiritual and gather in large numbers to pray, to appease the spirit of their ancestors. Children are often involuntarily taken to these religious gatherings where they may be exposed to air-borne tubercle bacilli from an infected worshipper. Tracking such an infected child is a big challenge to the health authorities. Unknown to the parents or guardians that the child is infected, the situation becomes more severe until the child is very ill and having no insurance or no money for hospitalization, the child may be taken to the traditional medical practitioner, who diagnoses the effect of evil spirit and prescribes sacrifices, or to spiritual houses that order for fasting for people who are already on the verge of starvation.

\section{Tetanus}

Tetanus is an acute disease of the nervous system caused by the contamination of wounds (e.g. cut umbilical cords in neonates) by the spores of a soil bacterium known as Clostridium tetani. Though the disease occurs worldwide, its rate is much higher in Africa and in Western Pacific [25]. It is called neonatal tetanus only when the disease affects new-born babies in their first 28 days of life. An earlier study reported 26.6 per 100,000 annual incidence and $14.6 / 100,00$ mortality [26]. A facility-based study reported that though the disease had the 
lowest frequency $(16,7.1 \%)$ among all diagnoses but mortality $(62.5 \%)$ was one of the highest [27] (Table 1).

Table 1 Major causes of mortality in children emergency room (CHER) in Nigeria; FMC: Federal Medical Center; UMCMS: University of Maiduguri College of Medical Sciences.

\begin{tabular}{|c|c|c|c|c|c|c|c|c|c|c|}
\hline State & $\begin{array}{l}\text { Location, } \\
\text { Authors } \\
\text { and year } \\
\text { of study }\end{array}$ & $\begin{array}{l}\text { Duration of } \\
\text { study }\end{array}$ & $\begin{array}{l}\text { Total } \\
\text { admitt } \\
\text { ed }\end{array}$ & $\begin{array}{l}\text { No. } \\
\text { that } \\
\text { died }\end{array}$ & $\begin{array}{l}\text { Morta } \\
\text { lity } \\
\text { rate }\end{array}$ & $\begin{array}{l}\text { Mean } \\
\text { age at } \\
\text { death }\end{array}$ & $\begin{array}{l}\text { Male/ } \\
\text { Female } \\
\text { ratio }\end{array}$ & $\begin{array}{l}\text { Death } \\
\text { within } \\
24 \mathrm{~h} \text { of } \\
\text { admiss } \\
\text { ion }\end{array}$ & Major causes of death & $\begin{array}{l}\text { Months of most } \\
\text { deaths }\end{array}$ \\
\hline Abia & $\begin{array}{l}\text { Federal } \\
\text { Medical } \\
\text { Center, } \\
\text { Umuahi a, } \\
\text { Southeast } \\
\text { zone, } \\
\text { Kimang'a, } \\
2012 \text { [59] }\end{array}$ & $\begin{array}{lr}5 & \text { years } \\
\text { January } & 1, \\
2004 & \text { to } \\
\text { December } & 31, \\
2008 & \end{array}$ & 3814 & 434 & $11 \%$ & $\begin{array}{l}1.7 \\
\text { years }\end{array}$ & $\begin{array}{l}238 / 196 \\
(1.2: 1)\end{array}$ & $49 \%$ & 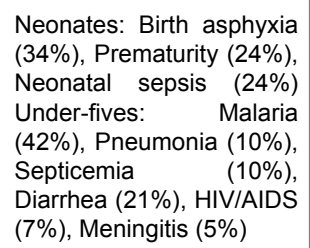 & $\begin{array}{l}\text { July (12\%), May } \\
(12 \%), \quad \text { March } \\
(11 \%)\end{array}$ \\
\hline Delta & $\begin{array}{l}\text { FMC, } \\
\text { Asaba } \\
\text { South- } \\
\text { South } \\
\text { zone, } \\
\text { Entwistle, } \\
2015 \text { [60] }\end{array}$ & $\begin{array}{lr}5 & \text { years } \\
\text { January } & 1, \\
2004 & \text { to } \\
\text { December } & 31, \\
2008\end{array}$ & 3830 & 221 & $5.80 \%$ & $\begin{array}{l}\text { Not } \\
\text { stated } \\
\text { (only>7 } \\
0 \% \\
\text { were } \\
\text { under } 5 \\
\text { years) }\end{array}$ & $\begin{array}{l}2189 / 16 \\
41 \\
(1.3: 1)\end{array}$ & $\begin{array}{l}\text { Not } \\
\text { stated }\end{array}$ & $\begin{array}{lr}\text { Neonates: not } & \text { stated } \\
\text { Under-fives: } & \text { Complicated } \\
\text { malaria }(27.4 \%), & \text { Sepsis } \\
(20.4 \%), & \text { Diarrheal } \\
\text { diseases } & (21 \%), \\
\text { Respiratory } & \text { Tract } \\
\text { Infection }(8.6 \%), & \text { Severe } \\
\text { acute malnutrition } & (7.0 \%) \\
\text { Five and } & \text { above: } \\
\text { Complicated } & \text { malaria } \\
(8.6 \%), \text { Sepsis } & (17.2 \%), \\
\text { Diarrheal riseases } \\
(2.9 \%), \text { Respiratory Tract } \\
\text { Infections }(2.9 \%)\end{array}$ & Not stated \\
\hline Oyo & $\begin{array}{l}\text { University } \\
\text { College } \\
\text { Hospital, } \\
\text { lbadan } \\
\text { South- } \\
\text { west zone, } \\
\text { Eko, 2017 } \\
\text { [61] }\end{array}$ & $\begin{array}{l}5 \quad \text { years } \\
\text { January } 1996 \\
\text { to December } \\
2000\end{array}$ & $\begin{array}{l}12,52 \\
2\end{array}$ & 1185 & $9.50 \%$ & $\begin{array}{l}\text { Not } \\
\text { stated }\end{array}$ & $\begin{array}{l}\text { Not } \\
\text { stated }\end{array}$ & $48.80 \%$ & $\begin{array}{l}\text { Neonatal: } 50.8 \% \text { of all } \\
\text { deaths, Neonatal tetanus, } \\
\text { Prematurity/LBW, } \\
\text { Neonatal septicemia, } \\
\text { Severe Birth Asphyxia, } \\
\text { Meningitis, Severs } \\
\text { Malnutrition and Measles, }\end{array}$ & Not stated \\
\hline Lagos & $\begin{array}{l}\text { Massey } \\
\text { Street } \\
\text { Children's } \\
\text { Hospital, } \\
\text { Lagos, } \\
\text { South- } \\
\text { west zone, } \\
\text { Stuckler, } \\
2010 \text { [62] }\end{array}$ & $\begin{array}{l}3 \text { years March } \\
2005 \text { to } \\
\text { February, } \\
2007\end{array}$ & $\begin{array}{l}224 \\
\text { neona } \\
\text { tes }\end{array}$ & 76 & $\begin{array}{l}33.90 \\
\%\end{array}$ & 7.3 days & $\begin{array}{l}135 / 89 \\
(1.5: 1)\end{array}$ & $\begin{array}{l}\text { Not } \\
\text { stated }\end{array}$ & $\begin{array}{lr}\text { Neonates: } & \text { Neonatal } \\
\text { septicemia } & (42.1 \%), \text { Birth } \\
\text { asphyxia } & (17.1 \%), \\
\text { Jaundice } & (17.1 \%), \\
\text { Neonatal tetanus } & (13.2 \%)\end{array}$ & Not stated \\
\hline Bauchi & $\begin{array}{l}\text { UMCMS, } \\
\text { North-east } \\
\text { zone, } \\
\text { Sreter, } \\
2003 \text { [63] }\end{array}$ & $\begin{array}{l}1 \quad \text { year } \\
\text { January- } \\
\text { December } \\
2012\end{array}$ & 1161 & 123 & 10.6 & $\begin{array}{l}6.2 \\
\text { years }\end{array}$ & $\begin{array}{l}576 / 585 \\
0.98: 1\end{array}$ & $\begin{array}{l}\text { Not } \\
\text { stated }\end{array}$ & \begin{tabular}{lr} 
Severe malaria & $(49.6 \%)$, \\
Protein & Energy \\
Malnutrition & $(8.1 \%)$ \\
Pneumonias & $(8.1 \%)$, \\
Sepsis $(7.3 \%)$, & Acute \\
Diarrheal Disease & $(5.0 \%)$, \\
\multicolumn{2}{l}{ Meningitis $(3.3 \%)$}
\end{tabular} & Not stated \\
\hline
\end{tabular}

In Nigeria, tetanus mortality rate varies from $38 \%$ to $60 \%$, depending on the infrastructure facilities and personnel at the reporting center [28]. Neonatal tetanus (NNT) is a significant cause of death among babies in the first 28 days of life [29]. A study found the prevalence rate of NNT in the northeast region between January 2008 and December 2013 to be approximately $28.8 \%$. Upsurge in tetanus might be associated with factors of cultural barriers which thwart pregnant women's effort in accessing antenatal care services; little or non-existing community awareness of neonatal tetanus; inability to access quality ANCs/delivery at the rural areas; religious beliefs; preference for home deliveries in the rural areas; and lack of trained TBA [30-32]. Tetanus (Clostridium tetani) has been subdued mostly in urban residence. However, if pregnant women revert to cutting the umbilical cord with unhygienic instruments or applying unclean solution to the navel, we may see a rise in the proportion of children with tetanus. 


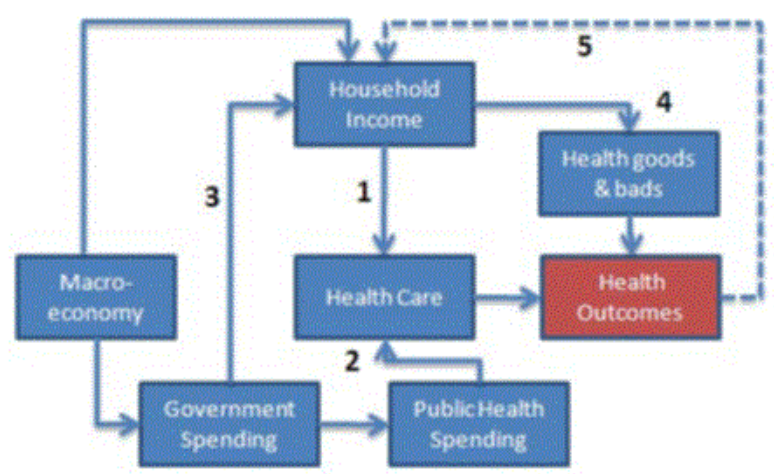

Figure 4 Health and wealth: simplified causal relationships, various routes through which recession may impact on health outcomes, the numbers in this figure link to textual references [21].

\section{Cancrum oris (NOMA)}

A previous study reported that children aged 2-12 years who live in close proximity with livestock and those with poor oral hygiene are susceptible to acute necrotizing gingivitis (ANG) or NOMA [33]. The study also found that the general living conditions and level of good oral hygiene were significantly higher in the Southwest than in the Northwest of Nigeria. NOMA, also known as Cancrum oris, has been described as a highly destructive, severe oro-facial gangrene which affects the soft and hard tissues of the mouth, face and neighboring areas $[34,35]$. Earlier studied had also identified malnutrition as a risk factor for both ANG and NOMA [36-40]. Financial recession, if prolonged, is expected to lead to chronic malnutrition by many intertwining and complex biochemical and behavioral pathways (Figure 4) predisposing children to many diseases such as NOMA.

\section{Viral diseases-Measles, hepatitis, polio, HIV}

Sub-Saharan countries where there is lingering economic recession, such as Nigeria, are also likely to witness a rise in the prevalence of viral diseases, such as measles, hepatitis (jaundice) and polio. These diseases may be sporadic or come in pockets of epidemics (Table 2 ).

Table 2 Childhood morbidity studies in Nigeria between 1996 and 2014.

\begin{tabular}{|c|c|c|c|c|c|c|c|c|}
\hline \multirow{2}{*}{ State } & \multicolumn{2}{|c|}{ Study } & \multirow{2}{*}{$\begin{array}{l}\begin{array}{l}\text { Total } \\
\text { admitted }\end{array} \\
\begin{array}{l}\text { Neonates } \\
(\%)\end{array}\end{array}$} & \multirow{2}{*}{$\begin{array}{l}\text { Male/ } \\
\text { Female } \\
\text { ratio }\end{array}$} & \multirow{2}{*}{$\begin{array}{l}\text { Mean } \\
\text { age } \\
\text { (month } \\
\text { s) }\end{array}$} & \multicolumn{3}{|c|}{ Major illnesses diagnosed } \\
\hline & $\begin{array}{l}\text { Location, Authors, } \\
\text { Year }\end{array}$ & Duration & & & & $\begin{array}{l}\text { Under-5 s } \\
(\%)\end{array}$ & $\begin{array}{l}5 \text { years and } \\
\text { above (\%) }\end{array}$ & \\
\hline Zamfara & $\begin{array}{l}\text { Gusau, Northwest } \\
\text { zone, Ensor et al., } \\
2010 \text { [64] }\end{array}$ & $\begin{array}{l}1 \text { year April } 12013- \\
\text { March 31, } 2014\end{array}$ & 801 & $\begin{array}{l}449 / 352 \\
1.3: 1\end{array}$ & 49.4 & Not stated & $\begin{array}{l}64.9 \% \text { of all } \\
\text { admissions: } \\
\text { Measles } \\
(100 \%), \text { PEM } \\
(90.6 \%), \\
\text { Diarrheal } \\
\text { diseases } \\
(88.5 \%) \text {, } \\
\text { Pneumonia } \\
(85.4 \%), \\
\text { Sepsis } \\
(68.0 \%), \\
\text { Malaria } \\
(64.3 \%), \\
\text { Cholera } \\
(57.1 \%)\end{array}$ & 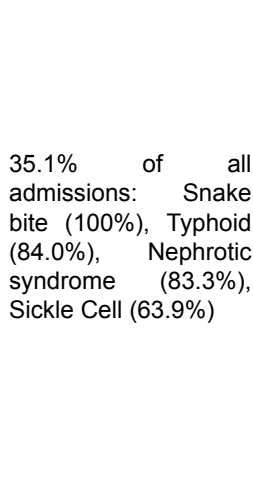 \\
\hline Delta & $\begin{array}{l}\text { FMC, Asaba South- } \\
\text { South } \\
\text { Entwistle, } 2015 \text { [60] }\end{array}$ & $\begin{array}{l}5 \text { years Jan } 2007 \text { to } \\
\text { Dec } 2011\end{array}$ & 3830 & 1.3:1 & 39.3 & Not stated & $\begin{array}{l}\text { Malaria } \\
(33.6 \%), \\
\text { RTIs } \\
(27.4 \%), \\
\text { Diarrheal } \\
\text { diseases } \\
(29.6 \%), \\
\text { Sepsis } \\
(6.1 \%), \\
\text { Sickle cell } \\
\text { crisis }(1.7 \%), \\
\text { Asthma } \\
(1.6 \%)\end{array}$ & 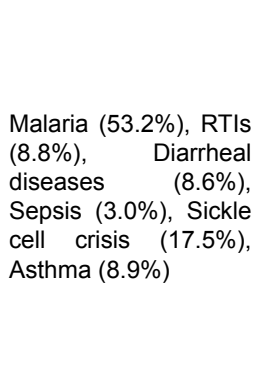 \\
\hline
\end{tabular}




\begin{tabular}{|c|c|c|c|c|c|c|c|c|}
\hline Plateau & $\begin{array}{l}\text { Vom Christian } \\
\text { Hospital University of } \\
\text { Jos, North-central } \\
\text { zone, Charles et al., } \\
2014 \text { [65] }\end{array}$ & $\begin{array}{l}1 \text { year May } 2012 \text { to } \\
\text { April } 2013\end{array}$ & 334 & $\begin{array}{l}191 / 143 \\
1.3: 1\end{array}$ & $\begin{array}{l}\text { Not } \\
\text { stated } \\
\text { (Under } \\
5 \\
\text { were s } \\
70.4 \% \text { ) }\end{array}$ & Not stated & $\begin{array}{l}\text { Malaria } \\
(30.2 \%), \\
\text { Septicemia } \\
(21.7 \%), \\
\text { Acute } \\
\text { bacterial } \\
\text { meningitis } \\
(5.5 \%) \text {, Acute } \\
\text { gastroenteriti } \\
\text { s }(6.0 \%) \text {, } \\
\text { Pneumonia } \\
(7.2 \%), \\
\text { Sickle cell } \\
\text { disease } \\
(2.6 \%) \\
\text { Severe PEM } \\
(1.7 \%)\end{array}$ & $\begin{array}{ll}\text { Malaria } & (31.3 \%) \\
\text { Acute } & \text { bacterial } \\
\text { meningitis } & (11.1 \%), \\
\text { Acute gastroenteritis } \\
(6.1 \%), \quad \text { Sickle cell } \\
\text { disease }(24.2 \%)\end{array}$ \\
\hline Lagos & $\begin{array}{l}\text { MSCH, Southwest } \\
\text { zone, Ezeonwu et al., } \\
2014 \text { [66] }\end{array}$ & $\begin{array}{l}1 \text { year April } 1996 \text { to } \\
\text { March } 1997\end{array}$ & 446 & $\begin{array}{l}255 / 191 \\
1.3: 1\end{array}$ & $\begin{array}{l}3.05 \\
\text { months }\end{array}$ & $\begin{array}{l}\text { ARI }(23.5 \%) \text {, } \\
\text { Malaria } \\
(4.4 \%), \\
\text { Gastroenterit } \\
\text { is }(7.4 \%) \text {, } \\
\text { Failure to } \\
\text { grow } \\
(14.7 \%) \text {, } \\
\text { Septicaemia } \\
(16.2 \%)\end{array}$ & $\begin{array}{l}>1 \text { month-6 } \\
\text { months: ARI } \\
(96.8 \%), \\
\text { Malaria } \\
(56.2 \%), \\
\text { Gastroenteriti } \\
\text { s }(90.9 \%) \text {, } \\
\text { Failure to } \\
\text { grow } \\
(86.1 \%), \\
\text { Septicemia } \\
(45.0 \%)\end{array}$ & Not studied \\
\hline
\end{tabular}

\section{Measles}

Measles is an extremely infectious disease which is still endemic, devastating and associated with a considerable morbidity and mortality especially in under-fives in sub-Saharan Africa, notwithstanding that effective and safe vaccine is accessible and obtainable [41]. The disease is endemic in Nigeria, occurring throughout the year though there is high measles routine and supplemental immunization coverage [42].

A study reported that the mean incidence of measles as 19 cases per 100,000 population/year, that under-fives accounted for the highest reported cases $(76.30 \%)$ while the under 1 year recorded highest mortality (53.8\%) [43].

Sporadic spread of measles may occur during economic crisis. Measles, being a highly contagious air-borne disease of viral origin (paramyxovirus family), spread through direct contact. Measles virus infects the lungs and the respiratory tract primarily and eventually spreads throughout the entire body. In 2014, the World Health Organization warned that progress towards eliminating the diseases had stalled and that the deprived progress in increasing measles vaccination coverage had resulted in large outbreaks of measles [44]. There are already reports of outbreaks of measles in some parts of the country but whether these are directly linked to the current economic crises is uncertain.

\section{Polio}

Poliomyelitis, or polio, is a highly infectious viral disease which in most cases affects young children. According to WHO [45], the virus is spread by person-to-person primarily through the faecooral route (Figure 5) or in some cases by contaminated water or food. The virus multiplies in the intestine and later invades the nervous system to cause permanent paralysis in children. Toddlers (Figures $\mathbf{5}$ and $\mathbf{6}$ ), who are most at risk for malnutrition, are also at risk for the transmission of polio which, as of now, has no cure but is preventable by oral polio vaccine (OPV) immunization. The country is almost free of polio but its resurgence cannot be ruled out in the present economic crisis. In fact, in 2016, there was a report of an outbreak in violencewracked north-eastern area where three cases have been reported in Jere, Gworza and Monguno districts [46]. Surveillance of acute flaccid paralysis due to poliomyelitis may be affected by the current economic recession due to nonavailability of resources.

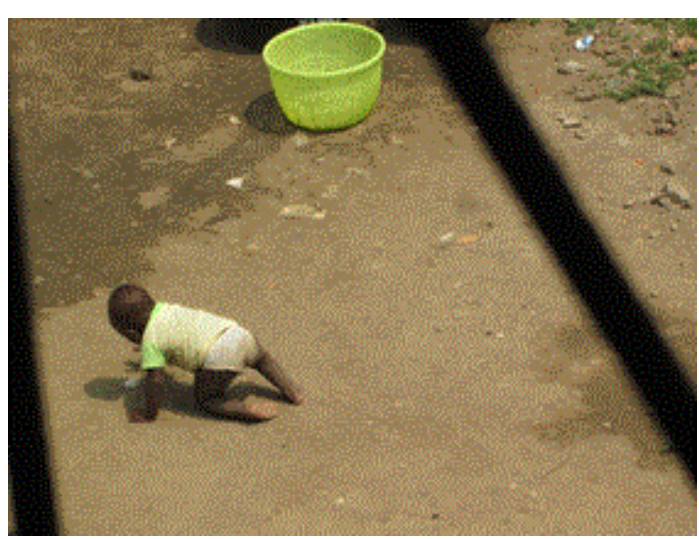

Figure $5 \mathrm{~A}$ toddler crawling on dirty ground.

Human Immuno-Deficient Virus. It is also possible to see a rise in pediatric HIV which may be spread by many pathways among which are heterosexual transmission leading to mother-to-childtransmission. HIV may therefore spread to the unborn child through an indirect pathway. Unlike other African countries whose HIV prevalence declined appreciatively-Malawi by $67 \%$; Botswana, Ethiopia, Ghana, Mozambique, Namibia, South Africa and Zimbabwe by more than $50 \%$-Nigeria only achieve a $19 \%$ 
decline and contributed $25 \%$ of new pediatric HIV infections in Global Plan priority countries in 2013 (51,000 cases) [47]. Since 2005 , there has been no reduction in the number of annual deaths, indicative of the fact that only $20 \%$ of people living with HIV in Nigeria are accessing antiretroviral treatment (ART) [47]. During the current economic recession, the proportion of people accessing ART may even decrease by both direct and indirect costs.

\section{Fever}

Although fever is a common response to infection (viral, bacterial or parasitic), its incidence is likely to surge upwards because of single infection or co-pathology especially among children. A study found that most (83\%) mothers regarded fever as hotness of the body and that only $44 \%$ of them identified infection as the most likely cause of fevers. Furthermore, malaria was presumptively diagnosed among $54 \%$ of the children by their mothers. However, though about $67 \%$ mother managed the fever at home by reducing the clothing and exposing the child to air, tepid sponging, and use of paracetamol, antimalarials (6.0\%) and antibiotics (7.8\%) group of drugs were rarely used [48].

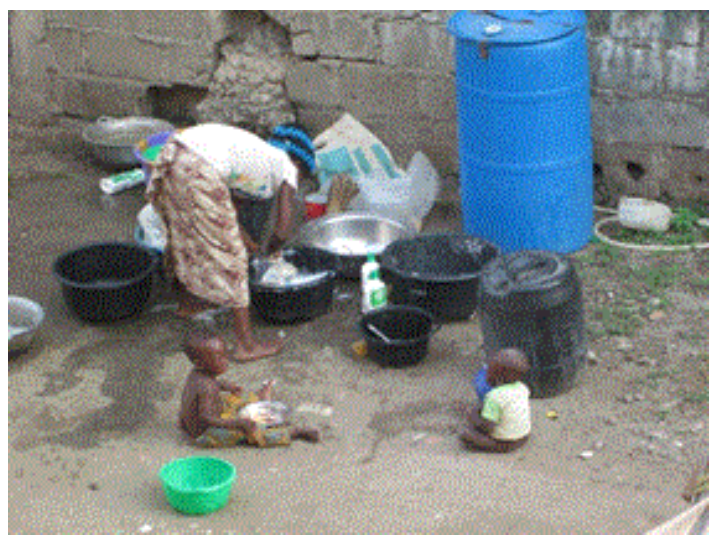

Figure 6 Male and female children sitting on bare ground; the male crying while the female has no underwear.

Malaria, measles and pneumonia, as well as viral infections (Tables 1 and 2), cause fever in the child and the prevalence of fever is also expected to rise due to increase in the prevalence/ incidence of each of these diseases. High fever indicates severity of the disease and convulsions are expected when these fever episodes are not brought down appropriately and adequately. Poor people, especially in rural areas, associate convulsion to evil spirit and may end up taking the child to and exorcist instead of to the health facility for proper management. Infant and child mortality may rise from this inappropriate action, needing massive health education.

The severity of these diseases is consequent upon two major factors (i) out-of-pocket expenditure from the household standpoint and (ii) health system strengthening, from the governmental perspective. Where there is economic recession, there are associated dwindling household funds for basic needs such as food, clothing, housing and medicine. Most African

children are not covered by any health insurance and this may put them in a vicious cycle of poverty, disease, illness and, eventually, death. This means that there may be virtually no health gains, especially for children and most especially for poor children, during economic recession. A study in South Africa reports that majority (71\%) of Black African children live in poverty [49], especially among the poorest, who bear the brunt of economic recession. This statement also applies to Nigeria, even before the current economic recession. Thus, the effects of economic crisis are borne mainly by poor people whose health decline and are most at risk for malnutrition and various diseases. The observed slow economic growth is expected to trap 46 million more people in poverty, (based on the United States dollar [US\$11.25-a-day-poverty line), added to a large number of people pushed into poverty globally due to food and fuel price increase [7].

\section{Malnutrition (weight-for-age z-score of <-2)}

As families slip into poverty during economic depression, malnutrition, especially in children and adolescents is one of the cardinal signs to indicate that food is scarcely available. Protein Energy malnutrition (PEM) is now rampant as a consequence of the economic recession, especially among internally displaced persons (IDPs) [50]. A report gave the prevalence of underweight (weight-for-age) among Nigerian under-5 children as $21.3 \%$ in 2014 [51]. Children less than 1 year are those that offer the least resistance against disease, malnutrition, and maltreatment, thus their death rates are affected most by negative economic shocks to the household [52]. There are already various reports of looming food crisis in Nigeria and that children are the most vulnerable [53]. The UN World Food Program estimated at least 4.5 million people, especially in North-east Nigeria, are now in need of emergency food aid [54]. To complement the efforts of the Federal Government, NonGovernmental Organizations such as Action Against Hunger cushions the effect of the economic recession by reaching at-risk mothers and children, providing education and safety nets, meeting basic survival needs and providing mothers with support systems. Other optional remedial activities include augmenting support for the rural farmers, strengthening rural credit schemes explicitly directed at the poor, distribution of vitamin A and iron supplements in rural health centers, encouraging production of low cost weaning diets and integrating nutrition education in primary health care schemes and in educational curricula [55].

\section{Impact of the economic recession on healthcare system and on surveillance and preventive measure on infectious diseases in Nigeria}

Disease control and prevention objectives are effectively achieved when existing resources are directed at improving the ability of health officials to distinguish the targeted diseases obtain laboratory confirmation of these diseases and use threshold to initiate action [56]. Outbreaks of communicable diseases have been public health challenges in Nigeria and recently, especially since the beginning of global economic recession, the frequency of such outbreaks has risen vastly. The recent Ebola virus disease indicates a need to strengthen the existing notifiable disease surveillance and notification system 
with increased clinicians' involvement in timely reporting of notifiable diseases to designated public health authorities for prompt public health action [57]. However, strengthening the notifiable disease surveillance may be an almost impossible task in the recent economic recession as resources - man, money, materials-are hardly available to effect the needed changes and to motivate health workers. Clinicians who are frequently the first contact a patient has with the healthcare system, may find themselves identifying the presence of infectious diseases, tracking and identifying cases and notifying designated public health authorities [57].

Furthermore, a study indicates that approximately $43 \%$ and $34 \%$ of health-workers indicated that their facilities have infection control unit and infection control committees respectively [58]. The indiscriminate use of antibiotics in humans and livestock, wrong and substandard prescriptions by unqualified 'medical personnel' together with poor diagnosis or lack of it are all adding fuel to the already fired train of resistant microbes [59].

\section{Integrated humanitarian assistance by NGOs}

The US Ambassador to Nigeria referred to the current insurgency in North-eastern Nigeria as "a complex humanitarian and economic crisis that has affected millions of people with about 1.5 million people displaced from their homes" [60]. There are quite a number of humanitarian organizations, or NGOs, currently providing assistance to the people of Nigeria during the recent economic crisis, including (i) Action against Hunger ( $\mathrm{AAH}$ ) which develops and runs emergency programs in nutrition, health, water and food security for countries in need (ii) Catholic Relief Services (CRS) which provides direct assistance where needed and which encourages people to help with their own development (iii) Doctors Without Borders or Medecin Sans Frontier (MSF) delivers medical help to populations endangered by war, civil strife, epidemics or natural disasters (iv) International Committee of the Red Cross (ICRC) promotes international humanitarian law and the fundamental human values underlying that law and (v) UNICEF which works to ensure the survival, protection and development of children and advocating a high priority for them in the allocation of resources at all times.

\section{Conclusion}

The economic recession in Nigeria has affected various sectors of the economy including the health sector leading to low productivity, poor service delivery and poor health outcome. Children and women are expected to be the most vulnerable groups. Children, especially, may be challenged with various bacterial, viral and fungal illnesses such as malaria, measles, meningitis, and pneumonia, which may be exacerbated by underlying malnutrition, a condition already rampant in the country. The Nigerian health sector is still striving to provide basic health care services with the collaborative efforts of the three tiers of government but efforts to achieve this seem unfeasible due to the current state of the Nigerian economy. The impact of economic recession on the Nigerian health care delivery system will likely include high cost of drugs, poor financing of the health sector, high cost of treatment, high disease morbidity and mortality, poor staff motivation, emergence of counterfeit drugs and increase in out-of-pocket expenditure on health care. Approaches to tackling the problems facing the health sector as a result of economic recession may include deliberate health policy reforms, complete administrative support in terms of stronger health sector financing and consolidation and incentivizing healthcare provider, institutionalizing comprehensive health care services and creating a well-organized monitoring and evaluation system [61].

There is an urgent need to put in place and implement interventions that can mitigate the health impact on children, especially those living in rural areas and urban slums who are among the poorest of the poor. Long-term effect of shorter-term economic crisis on children could include stunting, easting and malnutrition which form the basis of mortality in most cases. Most health programmes depend on a common system structure and recognizing these inter-relationships is increasingly seen as an important part of a development assistance strategy [62]. The challenge for today's policy makers is the design and implementation of mechanisms that protect vulnerable populations from the effects of fluctuating national income [63]. Recessions invariably have a negative association with maternal and infant outcomes [64]. It is suggested that the African Union (AU) should (i) constitute a group of professionals and consultants (Special Task Force) to deliberate and give annual report on the overall health of children and women (ii) derive a system where every African Child should benefit from Child Health Insurance and Child Support Grant, and every African woman should also benefit from Women Health Insurance and Women Support Grant (iii) liaise with the United Nations (UN) bodies such as World Health Organization and World Bank, specifically on these issues. Each African member country of AU should also emulate points (i) and (ii) above. This however, is a key issue to be considered as per whether the challenge can speed-up and scale-up the habitually problematic choice of regulating rare resources for the sake of mothers, neonates and children. A healthy Africa will be a much more productive continent than it currently is and the African Union has a major role to play in making this dream become a reality. The role of socio-economic factors is significant and without socio-economic epidemiology, biomedical epidemiology could make a limited contribution to the reduction of morbidity. 


\section{References}

1. Granados TJA, Diez Roux AV (2009) Life and death during the great depression. Proc Natl Acad Sci USA 106: 17290-17295.

2. How the depression affected children (2017).

3. UNICEF (2009) Aggregate shocks, poor households and children: Transmission channels and policy responses.

4. Mendoza R (2009) Aggregate shocks, poor households, and children: transmission channels and policy responses. Social policy working paper, division of policy and practice. New York.

5. Al-Masri Al-Yawm (2016) Elbalad.news, Egypt.

6. Meital C (2016) Three years into al-sisi's rule: Difficult challenges at home and abroad, MEMRI inquiry and analysis series report No. 1265.

7. Harper CN, McKay JA, Espey J (2009) Children in times of economic crisis: Past lessons, future policies. Background note prepared for UNICEF UK and the chronic poverty research centre, London: Overseas development institute.

8. The French revolution (1789-1799) (2010) Summary of events.

9. Cader AA, Perera L (2011) Understanding the impact of the economic crisis on child and maternal health among the poor: Opportunities for South Asia. ADB Institute. ADBI working paper series, No. 293. Tokyo: Asian development bank institute.

10. Okafor O (2016) How recession affects children's mental health.

11. Muanya C (2016) Nigeria: Tackling economic recession-induced mental health disorders (The Guardian).

12. UNICEF regional office South Asia (ROSA) (2009) A matter of magnitude: The impact of the economic crisis on women and children in South Asia. UNICEF ROSA.

13. Oluwole OS, Onabolu AO, Link H, Rosling H (2000) Persistence of tropical ataxic neuropathy in a Nigerian community. J Neurol Neurosurg Psychiatry 69: 96-101.

14. Adamolekun B (2010) Thiamine deficiency and the aetiology of tropical ataxic neuropathy. Int Health 2: 17-21.

15. Bogoch II, Brady OJ, Kraemer MUG, German M, Creatore M, et al. (2016) Potential for Zika virus introduction and transmission in resource-limited countries in Africa and the Asia-Pacific region: A modelling study. Lancet Infect Dis 6: 1237-1245

16. Akanbi MO, Ukoli CO, Erhabor GE, Akanbi FO, Gordon SB (2009) The burden of respiratory disease in Nigeria. African Journal of Respiratory Medicine 3: 10-18.

17. Macfarlane JT, Adegboye DS, Warrell MJ (1979) Mycoplasma pneumoniae and the aetiology of lobar pneumonia in northern Nigeria. Thorax 34: 713-719.

18. Nwosu CM, Anisiuba BC (1991) A hospital study of adult community acquired pneumonia: Clinical and microbiological characteristics and response to penicillin. Orient J Med 3: 138-141.

19. Musa BM, Tijjani BM, Okpapi JU, Borodo MM, Babashani M, et al. (2008) Bacterial isolates and antibiotic sensitivity in community acquired pneumonia. Niger Med J 49: 63-66

20. Iliyasu G (2011) Clinical pattern and profile of invasive pneumococcal infection in aminu kano teaching hospital. FMCP dissertation. Natl Postgrad Med Coll Nigeria. In: Iliyasu G, Habib AG, Borodo MM, Babashani M, Ahmed M. Pneumococcal
Infection in Nigeria: Preparing for the Vaccine. Sub-Saharan Afr J Med1: 15-19.

21. Falade AG, Mulholland EK, Adegbola RA, Greenwood BM (1997) Bacterial isolates from blood and lung aspirate cultures in Gambian children with lobar pneumonia. Ann Trop Paediatr 17: 315-319.

22. Nwachukwu U (2010) A tool to help mitigate this CSM outbreak in our Nation. Tropical Health Update.

23. World health organization global tuberculosis report 2014.

24. Daniel OJ, Adejumo OA, Abdur-Razzaq HA, Ebunoluwa JO (2015) Trend of childhood TB case notification in Lagos, Nigeria, 2011-2014. Int J Mycobacteriol 4: 239-244.

25. Emeribe VC, Akah LU (2011) Neonatal tetanus in African children: Causes, symptoms, predisposing factors, prevention and control. Arts Soc Sci J 2011: 1-4.

26. Johnstone DD (1958) Tetanus in Nigeria; review of 100 cases treated in Ibadan. Br Med J: 12-16.

27. Afolabi BM, Clement CO, Inem V (2013) A review of neonatal morbidity and mortality in an intensive care unit of a paediatric health facility in Lagos, Nigeria. J Trop Dis 1: 115.

28. Ogunrin OA (2009) Tetanus-A review of current concepts in management. J Postgrad Med 11: 46-61.

29. Peterside O, Duru CO, George BO (2012) Neonatal tetanus at the Niger Delta university teaching hospital: A 5 year retrospective study. Internet J Pediatr Neonatol 14: 1.

30. Akani NA, Nte AR, Oruamabo RS (2007) Neonatal tetanus in Nigeria: One social scourge too many! Nig J Paediatr 3: 1-9.

31. Eregie CO, Oforwe G (1995) Factors associated with neonata tetanus mortality in Northern Nigeria. East Afr Med J 72: 507-509.

32. Sani MN, Galadima M, Ameh JB, Kawo AH, Kurawa SM (2010) Serological evaluation of protective immunity against tetanus in pregnant women attending some rural hospitals in Kano, Northern Nigeria. Bayero J Pure Appl Sci 3: 39-42.

33. Idigbe EO, Enwonwu CO, Falkler WA, Ibrahim MM, Onwujekwe D, et al. (1999) Living conditions of children at risk for noma: Nigerian experience. Oral Dis 5: 156-162.

34. Tempest MN (1966) Cancrum oris. Br J Surg 53: 949-969.

35. Enwonwu CO (1972) Epidemiological and biochemical studies of necrotizing ulcerative gingivitis and noma (cancrum oris) in Nigerian children. Arch Oral Biol 17: 1357-1:171.

36. Loesche WJ, Syed SA, Laughon BE, Stoll J (1982) The bacteriology of acute necrotizing ulcerative gingivitis. J Periodontol 53: 223-230.

37. Sabiston CB Jr (1986) A review and proposal for the etiology of acute necrotizing gingivitis. J Clin Periodontol 13: 727-734.

38. Osuji OO (1990) Necrotizing ulcerative gingivitis and cancrum oris (noma) in Ibadan, Nigeria. J Periodontol 61: 769-772.

39. Taiwo JO (1993) Oral hygiene status and necrotizing ulcerative gingivitis in Nigerian children. J Periodontol 64: 1071-1074.

40. Enwonwu CO (1995) Noma: A neglected scourge of children in sub-Saharan Africa. Bull World Health Organ 73: 541-545.

41. World health organization (2014) Measles fact sheet No. 286 WHO media centre. 
42. Ameh CA, Sufiyan MB, Jacob M, Waziri NE, Olayinka AT (2016) Evaluation of the measles surveillance system in Kaduna State, Nigeria (2010-2012). Online J Public Health Inform 8: e206.

43. Oyefolu AOB, Oyero OG, Anjorin AA, Salu BO, Akinyemi KO, et al. (2016) Measles morbidity and mortality trend in Nigeria: A 10year hospital-based retrospective study in Lagos State, Nigeria. J Microbiol Infect Dis 6: 12-18.

44. WHO (2017) WHO warns that progress towards eliminating measles has stalled: 2015 targets will not be met.

45. WHO (2017) Poliomyelitis (polio).

46. Roberts L (2011) Extinct or possibly extinct?

47. UNAIDS (2014) The gap report 2014.

48. Oshikoya KA, Senbanjo IO (2008) Fever in children: Mothers' perceptions and their home management. Iran J Pediatr 18: 229-236.

49. UNICEF (2011) The global economic recession and child well-being in South Africa.

50. Ubesie A, Ibeziakor N (2012) High burden of protein-energy malnutrition in Nigeria: Beyond the health care setting. Ann Med Health Sci Res 2: 66-69.

51. Index mundi (2017) Malnutrition prevalence.

52. Fishback PV, Haines MR, Kantor S (2002) The welfare of children during the great depression. National bureau of economic research (NBER) working paper no. 8902, JEL No. I38, J11, N32.

53. Singh L (2017) Malnutrition is killing Nigeria's children because of food shortage.

54. Al-Jazeera television (2017) News.

55. Igbedioh SO1 (1993) Undernutrition in Nigeria: Dimension, causes and remedies for alleviation in a changing socio-economic environment. Nutr Health 9: 1-14.
56. Federal ministry of health (2009) National technical guidelines for integrated diseases surveillance and response, Abuja: Federal ministry of health, pp: 2-69.

57. Isere EE, Fatiregun AA, Ajayi 10 (2015) An overview of disease surveillance and notification system in Nigeria and the roles of clinicians in disease outbreak prevention and control. Niger Med J 56: 161-168.

58. Osuala EO, Oluwatosin OA (2017) Infection control by nurses in selected hospitals in Anambra State, Nigeria. Trop J Med Res 20 53-60.

59. Kimang'a AN (2012) A situational analysis of antimicrobial drug resistance in Africa: Are we losing the battle? Ethiop J Health Sci 22: $135-143$

60. Entwistle JF (2015) US ambassador to Nigeria. In: USAID grant signing ceremony, US embassy, Abuja, Nigeria.

61. Eko JE (2017) Implication of economic recession on the health care delivery system in Nigeria. Soc Sci 6: 14-18.

62. Stuckler D, Basu S, McKee M (2010) Drivers of inequality in millennium development goal progress: A statistical analysis. PLoS Med 7: e1000241.

63. Sreter S (2003) Public health then and now. Am J Public Health 93 421-431.

64. Ensor T, Cooper S, Davidson L, Fitzmaurice A, Graham WJ (2010) The impact of economic recession on maternal and infant mortality: Lessons from history. BMC Public Health 10: 727.

65. Charles NC, Chuku A, Anazodo NM (2014) Childhood mortality in federal medical centre, Umuahia, South-eastern Nigeria. Oman Med J 29: 320-324.

66. Ezeonwu BU, Chima OU, Oguonu T, Ikefuna AN, Nwafor I (2014) Morbidity and mortality pattern of childhood illnesses seen at the children emergency unit of federal medical center, Asaba, Nigeria. Ann Med Health Sci Res 4: S239-S244. 